\title{
Opšta fizička priprema seniorki u košarci
}

\author{
Jelena Škrbić \\ Sandra Vujkov \\ Visoka strukovna škola za obrazovanje vaspitača i trenera, Subotica
}

\begin{abstract}
In this paper general physical preparation women seniors in basketball is described through four phases with examples and exercises for development of certain physical abilities that are prevalent in today's basketball.
\end{abstract}

Sažetak: U ovom radu opisuje se opšta fizička priprema seniorki u košarci kroz četiri faze i sa primerima vežbi za razvoj određenih fizičkih sposobnosti koje su zastupljene u današnjoj košarci.

Keywords: physical preparation, basketball

Ključne reči: fizička priprema, košarka

Rad je primljen 18.05.2016.

Odobren 23.05.2016.

Kontakt podaci:

Jelena Škrbić

Visoka škola strukovnih studija za obrazovanje vaspitača i trenera

Subotica, Ferenci Ibolje 3a,

Tel: +381628913145

E-mail: skrbic.jelena@yahoo.com 


\section{Uvod}

Košarka predstavlja jedan od najznačajnijih sportova današnjice, te se samim tim ulažu veliki napori za njeno aktivno osavremenjavanje. Osnovna jedinica košarke je, naravno, igrač, čija igra i kvalitet zavise od velikog broj faktora, među kojima je i kondicija (Milanović, 1991). Iz godine u godinu sve su zahtevniji zadaci pred košarkašicama i zbog toga je sve veća potreba za što kvalitetnijom fizičkom pripremom. To podrazumeva da se u pripremnom period moraju određivati takva opterećenja na treningu, koja neće imati negativno dejstvo na košarkašice u kasnijem takmičarskom period (Milanović, 1991). Drugim rečima, igračice ne treba da su pretrenirane, odnosno, zasićene treningom, već da su željne dokazivanja kako na treningu, tako i na trening utakmicama. Način pripreme košarkašica u velikoj meri zavisi od nivoa njihovih morfoloških, funkcionalnih, antropomotoričkih karakteristika, uzrasta i iskustva. Svaki organizam ima složeni tok razvoja. Uloga trenera je da kroz trenažni proces podstiče taj razvoj. Potrebno je pravilno razvijati sve sposobnosti organizma, a ne samo one koje su najneophodnije datoj sportskoj grani, tzv. jednostrana specijalizacija, jer je ona u suprotnosti sa prirodnim tokom razvoja organizma. Košarka obuhvata kompleksnu motoričku aktivnost u okviru koje se realizuje veliki broj složenih, promenjivih i nepredvidivih kretanja i situacija koje zahtevaju najbolje odgovore. Da bi došao do tog nivoa odgovora, igračice moraju imati razvijenu (do automatizma) strukturu kretanja. Takva obučenost i kvalitet zavise od čitavog niza različitih uticaja. Košarka, sa stanovišta strukture kretanja i struktura situacija je kompleksna - čine je kompleksi jednostavnih i složenih kretanja, odnosno, jedna je od najsloženijih motoričkih igara, kojom dominiraju transformacije iz akcije u akciju. Fizička priprema se može definisati kao niz planiranih metodskih postupaka, prvenstveno usmerenih ka transformaciji motoričkog statusa pojedinca. Kao sinonimi koriste se kondiciona priprema i bazična priprema (Milanović, 1991). Cilj ovog rada jeste da se shvati značaj fizičke pripreme koja obezbeđuje optimalne preduslove, a pri tome se misli antropološke karakteristike pojedinca, za lakše i brže savladavanje sportskotehničkih zadataka u specifičnim uslovima. Cilj rada u fizičkoj pripremi realizuje se preko niza zadataka. Zadaci su usmereni na :

1. podizanje nivoa bazičnih motoričkih sposobnosti (snaga, brzina, izdržljivost, koordinacija, gipkost, ravnoteža, preciznost),
2. razvijanje funkcionalnih sposobnosti organizma sportiste (funkcije kardiovaskularnog, respiratornog i centralnog nervnog sistema),

3. promenu morfoloških karakteristika (količine potkožnog masnog tkiva, volumena i mase tela),

4. očuvanje i poboljšanje zdravlja (preventiva kardiovaskularnih i respiratornih oboljenja, podizanje imuniteta, preventiva sportskih povreda),

5. transformaciju psiho-socialnog statusa (jačanje ega, samopouzdanja,prilagođavanje grupi, i dr),

6. razbijanje monotonije $u$ treningu i na taj način produžavanje trajanja sportske forme,

7. aktivan oporavak posle niza specifičnih trenažnih i takmičarskih opterećenja.

\section{Podela fizičke pripreme}

Fizičke pripreme se dele na opštu i specifičnu fizičku pripremu. Pod opštom fizičkom pripremom podrazumeva se razvoj širokog spektra sposobnosti, od kojih se neke ne mogu direktno ispoljiti, već se javljaju tokom kasnijih specifičnih svojstava. Opšta kondiciona priprema usmerena je na poboljšanje svih topoloških regija tela, na podizanje efikasnosti svih organa i organskih sistema, na podizanje funkcionalnih sposobnosti, kao i primarne snage, brzine, izdržljivosti i gipkost. Na dužinu trajanja opšte fizičke pripreme utiče više faktora, kao što su: specifičnost sporta, godine, dužina bavljenja sportom, stanje treniranosti, ranije povrede. Specifična fizička priprema je orijentisana ka razvoju onih motoričkih i funkcionalnih sposobnosti koje su specifične za konkretnu sportsku granu. Sadržaji su isključivo vezani uz tehniku, a intenzitet se najčešće kreće od submaksimalnog do maksimalnog, intenzitet se znatno smanjuje u odnosu na opštu pripremu, a karakter i trajanje odmora približni su realnim energetskim uslovima sportske aktivnosti.

\section{Odnos opšte i specifične pripreme}

U teorijsko-praktičnom smislu postoji dijalektička povezanost oba oblika pripreme. Specifična fizička priprema služi kao nadogradnja bazične fizičke pripreme i obrnuto, što znači da je odnos između bazične i specifične pripreme neraskidivo povezan (Milanović, 1991). Razlike u fizičkoj pripremu u košarci, između muskaraca i žena, postoje samo u doziranju, tj. u jačini inteziteta i broju ponavljanja vežbi. Žene su po prirodi fizički slabije konstitucije i samim tim 
smanjuje se i njihova izdrzljivost, snaga i brzina u odnosu na muškarce.

\section{Opšta fizička priprema košarkašica u fazama}

Prva faza traje oko 15 dana. U ovoj fazi se teži postepenom uvođenju igre u sistematski trenažni proces, posle perioda letnje pauze. Izvode se treninzi aerobne izdržljivosti trčanja, kontinuirano ili intervalno-promenljivo, umerenim intenzitetom $\mathrm{u}$ kombinaciji sa skokovima manjeg intenziteta. Tendecija je da se svaki pojedinac osposobi da u ukupnom obimu pretrči do 7-8 km i izvede 2-4 serije skokova sa 200 ponavljanja. U ovom periodu bi trebalo realizovati od 6-8 treninga ovog tipa u zavisnosti od okolnosti. U teretani se izvode vežbe iz programa za razvoj snažne izdržljivosti. Radi se, takođe, sa umerenim opterećenjem 3 serije za mišićnu grupu, 15 ponavljanja $u$ seriji sa opterrćenjem $30 \%$ od 1RM. Smatra se da treba ostvariti 5 treninga ovog tipa u okviru prve faze.

Treninzi sa loptom (treninzi tehničkotaktičkog tipa), trebalo bi da dominantno sadrže u svom programu vežbe za poboljšanje koordinacije, fleksibilnosti, kao i sportske igre (odbojka,fudbal).

Druga faza traje 30 dana. Ona je fizički najzahtevnija, jer dolazi do povećanja obima $\mathrm{i}$ intenziteta rada u svim oblastima. Smišljeno se skraćuju periodi oporavka od opterećenja, izaziva se dubok zamor, a sve sa ciljem da se u kasnijim fazama rada pojavi nadkompenzacija koja predstavlja samopoboljšanje kondicione forme. $\mathrm{U}$ program rada se uvode treninzi brzinske izdržljivosti, koji se izvode intervalno-serijski u 40 ukupnom obimu od 2 do $3 \mathrm{~km}$ po treningu (6 do 10 serija $\times 300 \mathrm{~m}, 2$ do 3 serije $\times 1000 \mathrm{~m}, 3$ do 4 serije $\times 800 \mathrm{~m}$ ), sa tendencijom povećanja intenziteta rada do granice submaksimalnog. Trening bi se realizovao 8 - 12 puta u okviru druge faze. Treninzi aerobne izdržljivosti trčanja ostaju nepromenjenog karaktera, a izvode se od 4 do 6 puta $\mathrm{u}$ ovoj fazi. Program rada treba ukomponovati tako da se posle dva treninga brzinske izdržljivosti izvodi jedan trening aerobne izdržljivosti, kako bi se ostvario maksimalno koristan efekat treninga. U teretani se nastavlja rad na razvoju snažne izdržljivosti (7-9 treninga u drugoj fazi), ali uz povećavanje intenziteta opterećenja do $60 \%$ od RM 1 povećanje obima od 3 do 5 serija po mišićnoj partiji i smanjenja broja ponavljanja od 8 do 12 u seriji. Nakon ovih treninga uvode se treninzi submaksimalne $i$ maksimalne sile u teretani, koji se izvode jedanput nedeljno, odnosno, tri puta u okviru druge faze. Koristi se piramidalni metod rada, a najveći akcenat se stavlja na vežbe, kao što su: polučučanj, potisak šipke ramenima, potisak šipke listovima, benč potisak i povlačenje na lat mašini za leđne mišiće. Na treninzima sa loptom radi se tehnička i taktička obuka, ali bez insistiranja na intenzitetu rada i koordinacijskoj preciznosti izvođenja elemenata usled otežanog funkcionisanja organizama, zbog pojave dubokog zamora.

Treća faza traje 20 dana. U ovoj fazi dolazi do umerenog smanjenja obima opterećenja kondicionih treninga, a povećanja obima i intenziteta rada na treninzima tehničko-taktičkog tipa. Cilj je da se kondicioni potencijal transformiše $u$ onaj oblik manifestovanja koji odgovara realizaciji košarkaške igre. U ovoj fazi počinje se sa odigravanjem prijateljskih utakmica, ali se još uvek ne očekuje da tim pokazuje najviši stepen forme i kvalitete igre usled zamora. Trening brzinske izdržljivosti realizuje se 4 puta u trećoj fazi priprema, ali tako da posle dva ostvarena treninga sledi jedan trening aerobne izdržljivosti trčanja. Struktura samog treninga brzinske izdržljivosti ostaje nepromenjena po obimu i intenzitetu. U teretani vežbe za razvoj maksimalne sile izvode se dva puta u okviru treće faze, dok se u program uključuju i vežbe za poboljšanje eksplozivne i brzinske snage. Primenjuje se u četiri serije po 6-8 ponavljanja, dva puta u 15 dana.

Četvrta faza priprema traje 15 dana. U ovoj fazi usled adaptacionih promena i smanjenju stepena zamora $u$ organizmu, dolazi do manifestovanja efekta kondicione pripreme. Taj efekat se najbolje zapaža na treninzima tehničkotaktičkog tipa i na prijateljskim utakmicama, gde tim delimično dostiže nivo takmičarske forme. Treninzi aerobne izdržljivosti trčanja, brzinske izdržljivosti, izdržljivosti u snazi u teretani, realizuje se dva puta u 15 dana, jedino se trening za poboljšanje maksimalne sile trčanja realizuje četiri puta u datom periodu. Akcenat se posvećuje odigravanju većeg broja prijateljskih utakmica $\mathrm{i}$ taktičkom usavršavanju tima.

\section{Vežbe}

Na razvoj anaerobne izdržljivosti košarkašica seniorskih selekcija treba staviti veliki značaj, jer je jedna od polaznih osnovna za dalji uspešni razvoj ostalih motoričkih sposobnosti u košarci. Intenzitet opterećenja treba da iznosi između 60$70 \%$. Najbolje vežbe za razvoj anaerobne izdržljvosti su : 

$\min$,

- trčanje u prirodi umerenim tempom 20-30

- kros trčanje (2000-4000 m),

- trčanje (800-2000 m),

- duga intervalna trčanja $2-3$ x (1000-800600 ), odmor 2-4 min,

- duga intervalna trčanja $3-5 \times 2000 \mathrm{~m}$ (odmor 3-5 min),

- kraća intervalna trčanja 4 -5 x(600-400300), pauza 3-2-1 min,

- kraća intervalna trčanja $8 \times 500 \mathrm{~m}$, pauza $1.30 \mathrm{~min}$.

Zbog same prirode košarke, specifična izdržljivost je veoma značajna i treba raditi na njenom razvoju, kroz različite vežbe čiji je intezitet opterećenja od 85 do $95 \%$, neke od vežbi su:

- trčanje intervalnom metodom u deonicama 30-50 $\mathrm{m}$ sa vođenjem lopte hvatanjem i dodavanjem lopte i završnim ubacivanjem lopte u koš,

- igra na dva koša intervalnom metodom (npr.

$12 \times 5^{\prime}$,intenzitet opterećenja $85-95 \%$ ),

- vođenje lopte individualno, dodavanje lopte u paru i u troje na udaljenost $50 \mathrm{~m}$,

- kretanje na poligonima,

- izvođenje ubacivanja lopte u koš bez odmora,

- uvežbavanje tehnike i individualne tehnike u otežanim uslovima - igra u odbrani i napadu protiv brojčane nadmoći,

- igra na dva koša $\mathrm{s}$ manjim brojem igrača $4: 4, \quad 3: 3,2: 2$. Osnova treninga izdržljivosti uslovljena je razvojem aeorobnog i anaerobnog kapaciteta.

Faktor brzine je motorička sposobnost za brzo izvođenje, pre svega jednostavnih motoričkih zadataka, što je u košarci veoma bitno i zbog toga se treba razvijati na najvišem nivou. Najbolje vežbe za razvoj brzine su:

- takmičenja s brzinom $95-100 \%$ od max. brzine, 3-4 serije sa 4-5 ponavljanja, 2-4 min. pause,

- trčanje 50-100 $\mathrm{m}$, sa promenom tempa trčanja i sa ubrzanjem,

- trčanje niz stepenice (padinu),

- startovi iz različitih polaznih položaja sa istrčavanjem,

- trčanje u sprintu 10-60 m, sa promenom pravca,

- razne elementarne igre.

Košarka se često označava kao igra brzine. To je ispravno u pogledu brzine reakcije, gde košarkašce najčešće treba da reaguju na vizuelne signale, kao što su: protivničke igračice, saigračice, lopta, linije terena i drugo. Najbolje vežbe za razvoj specifične brzine su:

- vođenje lopte u sprintu pravolinijski između 5-50 m, sa i promenom pravca kretanja;

- hvatanje lopte u sprintu, kretanje i vođenje i dodavanje lopte;

- trčanje napred - nazad sa okretima za $90^{\circ}, 180^{\circ}, 360^{\circ}$;

- zaustavljanja, pivotiranja iz paralelnog i dijagonalnog stave, bez i sa protivnikom 3-6', 4-6 serija $30-601 / 2$, pauza $30-601 / 2$;

- razni oblici takmičenja u brzini vođenja lopte (sa i bez prepreka) na udaljenosti 10-40 m;

- trčanje maksimalnom brzinom u vezi sa određenim zadatkom;

- maksimalno brzi rad nogu (sa i bez opterećenja), vežbe u stavu (napred-nazad, bočno, levo-desno, usaglašavanje sinhronizovanog rada nogui ruku).

Košarkaška snaga je sposobnost suprodstavljanju tela košarkašica spoljašnjem otporu mišićnim naprezanjima. Eksplozivna snaga je veoma značajna u košarci i zbog toga se radi na njenom maksimalnom razvoju, kroz različite vežbe, a neke od njih su:

-Skokovi iz polučučnja $3 \times 15$, pauza $2 \mathrm{~min}$;

-Bočni skokovi sa noge na nogu 3 x 15, pauza 3 min;

-Sunožni odskoci iz skočnog zgloba 3 x 20, pauza $1 \mathrm{~min}$;

-Dodavanje medicinkom $(2 \mathrm{~kg})$ iznad glave 4 x 15 , pauza 2 min;

-Dodavanje medicinkom (2 kg) sa grudi $4 \mathrm{x}$ 15 , pauza 2 min;

-Nabačaj sa kolena sa štapom ili laganom šipkom 4 x 8 , pauza $3 \mathrm{~min}$;

-Skokovi preko prepone $3 \times 12$, pauza $3 \mathrm{~min}$; $3 \mathrm{~min}$

-Bočni skok sa opterećenjem 4 × 2 × 4 , pauza

-Dijagonalni skok sa opterećenjem 4 × $2 \times 4$, pauza $3 \mathrm{~min}$;

-Skok sa okretom za $90^{\circ}$ sa opterećenjem 4 x 2 x 4, pauza $3 \mathrm{~min}$;

-Benč pres sa izbacivanjem tereta $3 \times 10$, pauza $3 \mathrm{~min}$;

-Sklekovi sa odgurivanjem od podloge $4 \mathrm{x}$ 10 , pauza $3 \mathrm{~min}$. 


\section{Zaključak}

Košarka se kao i svaka druga sportska aktivnost, može posmatrati sa strukturalnog, biomehaničkog i funkcionalnog aspekta. Kompleksnost košarke ogleda se u velikom broju različitih faktora, čiji uticaj doprinosi uspehu ili neuspehu nekog tima. Kao jedan od najvažnijih faktora u ovom radu je analizirano poboljšanje kondicijske pripremljenosti iz više aspekata koji na nju deluju. Način pripreme košarkašica u velikoj meri zavisi od nivoa njihovih morfoloških i kondicijskih karakteristika, uzrasta $\mathrm{i}$ iskustva. Kondicijska pripremljenost predstavlja bazu na koju se nadograđuje tehničko-taktički kvalitet nekog tima i bez nje se u današnjoj košarci ne može ostvariti dobar takmičarski rezultat.

Kondicijska priprema je u poslednje vreme postala vrlo bitan i nezaobilazan faktor $\mathrm{u}$ košakaškoj igri, jer treba izdržati tokom jedne takmiščarske sezone da se odigra vise od četrdeset utakmica. Za takve napore mora se vrlo ozbiljno pristupiti planiranju i programiranju celokupnog trenažnog procesa košarkašica u kojoj prostor kondicije zauzima jedno od ključnih mesta.

Jednu od bitnih uloga u fizičkoj pripremi sportista ima trener. On provodi najviše vremena sa igračicama i samim tim i najbolje poznaje svoje igračice, shodno tome on ima jasnu sliku koliko može od njih da očekuje, koliki pritisak može da vrši nad njima, itd. Na osnovu svih parametara koje ima o svakoj pojedinačnoj igračici može prilagoditi fizičku pripremu prema njihovim mogućnostima, kako bi se na kraju dobili najbolji rezultati što je i krajnji cilj sporta. 


\section{Literatura}

1. Matković, B.; Knjaz, D.; Ćosić, B. (2003). Smjernice fizičke pripreme košarkaša. Zagreb, Kineziološki fakultet.

2. Milanović, D. (1991). Osnove sportskog treninga. Zagreb, [s.n.], 1991.

3. Karalejić, M., Ahmetović.Z., JakovljevićS., Novović, M.(1998). Košarka- priručnik za trenere. Beograd: KSS.

4. KaralejićM., Jakovljević S. (2001). Osnove košarke. Beograd, KSS. 